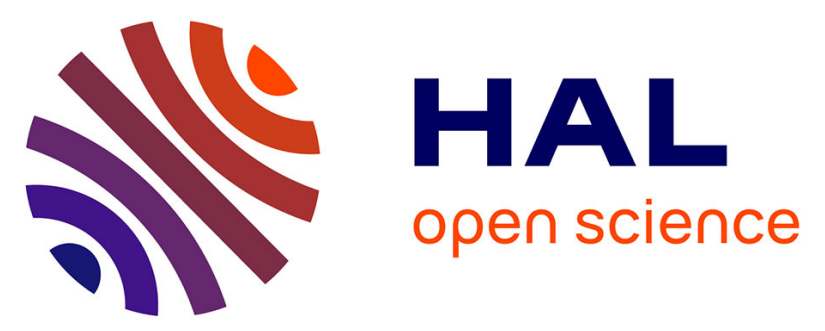

\title{
Occupational solvent exposure and risk of meningioma: results from the INTEROCC multicentre case-control study
}

\author{
Dave Mclean, Sarah Fleming, Michelle C Turner, Laurel Kincl, Lesley
} Richardson, Geza Benke, Brigitte Schlehofer, Klaus Schlaefer, Marie-Elise

Parent, Martine Hours, et al.

\section{To cite this version:}

Dave Mclean, Sarah Fleming, Michelle C Turner, Laurel Kincl, Lesley Richardson, et al.. Occupational solvent exposure and risk of meningioma: results from the INTEROCC multicentre case-control study. Occupational and Environmental Medicine, 2014, 71 (4), pp.253-258. 10.1136/oemed-2013-101780 . pasteur-01136021

\section{HAL Id: pasteur-01136021 \\ https://hal-riip.archives-ouvertes.fr/pasteur-01136021}

Submitted on 20 Mar 2019

HAL is a multi-disciplinary open access archive for the deposit and dissemination of scientific research documents, whether they are published or not. The documents may come from teaching and research institutions in France or abroad, or from public or private research centers.
L'archive ouverte pluridisciplinaire HAL, est destinée au dépôt et à la diffusion de documents scientifiques de niveau recherche, publiés ou non, émanant des établissements d'enseignement et de recherche français ou étrangers, des laboratoires publics ou privés. 
Occupational solvent exposure and risk of meningioma. Results from the INTEROCC multi-centre case-control study.

Dave McLean ${ }^{1}$, Sarah Fleming ${ }^{2}$, Michelle Turner $^{3}$, Laurel Kincl ${ }^{4}$, Lesley Richardson ${ }^{5}$, Geza Benke $^{6}$, Brigitte Schlehofer ${ }^{7}$, Klaus Schlaefer ${ }^{7}$, Jérôme Lavoué ${ }^{5}$, Marie-Elise Parent ${ }^{8}$, Martine Hours ${ }^{9}$, Javier Pintos ${ }^{5}$, Daniel Krewski ${ }^{10}$, Martie van Tongeren ${ }^{11}$, Siegal Sadetzki ${ }^{12}$, Jack Siemiatycki ${ }^{5}$, Elisabeth Cardis ${ }^{3}$

${ }^{1}$ Centre for Public Health Research, Massey University, Wellington, New Zealand

${ }^{2}$ University of Leeds, Leeds, United Kingdom

${ }^{3}$ Centre for Research in Environmental Epidemiology (CREAL), Barcelona, Spain

${ }^{4}$ Oregon State University, Corvallis, USA

${ }^{5}$ University of Montreal Hospital Research Centre (CRCHUM), Montreal, Canada

${ }^{6}$ Monash University, Melbourne, Australia

${ }^{7}$ DFKZ, Heidelberg, Germany

${ }^{8}$ INRS-Institut Armand-Frappier, Montreal Canada

${ }^{9}$ IFSTTAR - University of Lyon1, France

${ }^{10}$ University of Ottawa, Ottawa, Canada

${ }^{11}$ Institute of Occupational Medicine, Edinburgh, UK

${ }^{12}$ Gertner Institute, Chaim Sheba Medical Centre \& Tel Aviv university, Tel Aviv, Israel

\section{Corresponding author:}

David McLean

Centre for Public Health Research, Massey University, 102 Adelaide Road, Wellington, New Zealand.

\section{d.j.mclean@massey.ac.nz}

\section{Key words:}

brain cancer, case-control study, meningioma, solvents, job-exposure matrix. 


\section{Abstract}

Objective To examine associations between occupational exposure to selected organic solvents and meningioma.

Methodology A multi centre case-control study conducted in seven countries, including 1,906 cases and 5,565 controls. Occupational exposure to selected classes of organic solvents (Aliphatic and Alicyclic hydrocarbons, Aromatic hydrocarbons, Chlorinated hydrocarbons and "other" organic solvents) or seven specific solvents (Benzene, Toluene, Trichloroethylene, Perchloroethylene, 1,1,1-Trichloroethylene, Methylene chloride and gasoline) was assessed using lifetime occupational histories and a modified version of the FINJEM job-exposure matrix (INTEROCCJEM). Study participants were classified as "exposed" when they had worked in an occupation for at least 1 year, with a 5 -year lag, in which the estimated prevalence of exposure was $25 \%$ or greater in the INTEROCC-JEM. Associations between meningioma and each of the solvent exposures were estimated using conditional logistic regression, adjusting for potential confounders.

Results A total of $6.5 \%$ of study participants were ever exposed to "any" solvent, with a somewhat greater proportion of controls $(7 \%)$ ever exposed compared to cases $(5 \%)$, but only one case was ever exposed to any chlorinated hydrocarbon (1,1,1-Trichloroethane). No association was observed between any of the organic solvents and meningioma, in either men or women, and no dose response relationships were observed in internal analyses using either exposure duration or cumulative exposure.

Discussion We found no evidence that occupational exposure to these organic solvents is associated with meningioma. 


\section{Introduction}

Meningiomas are the most frequently diagnosed primary brain tumours, accounting for approximately $20 \%$ of all intracranial tumours in males and $38 \%$ in females in the United States (Claus et al 2005; Wiemels et al, 2010). The incidence of meningioma increases markedly with age, and the disease occurs at a ratio of approximately 2:1 in females compared with males. In contrast with other types of cancer, meningioma does not appear to be influenced strongly by lifestyle factors such as cigarette smoking, diet, and alcohol (Bondy et al, 2008; Fisher et al, 2007). The higher incidence in females, and the observation that meningioma is associated with a prior history of breast cancer (Schneider et al, 2005; Helseth et al, 1989; Schoenberg et al, 1975; Smith et al, 1978) suggests that hormonal factors (both endogenous and exogenous) may be involved in the aetiology in women (Bondy et al, 2008).

Much of the aetiological research on brain cancer conducted to date has investigated primary malignant brain tumours (which are predominantly gliomas), and relatively few have investigated specific risk factors for meningioma. Increased risks of all brain cancer types have been observed in a number of studies to be associated with specific occupations or occupational exposures, most notably: farming and pesticides (Musicco et al 1988; Ruder et al 2009; Rodvall et al 1996; Viel et al 1998), organic solvents

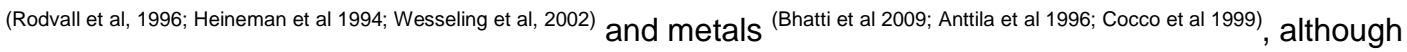

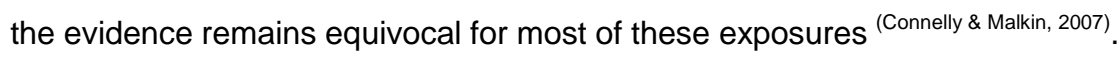

There have been relatively limited findings to date on environmental risk factors specifically for meningioma. The only established risk factors for meningioma are high-dose ionising radiation, with significantly elevated risk observed in atomic bomb survivors (Wrench et al, 2002), and following lower-dose radiation therapy given to Israeli children for scalp ringworm (Ron et al, 1988; Sadetzki et al, 2005), however these account for only a small proportion of cases. Several studies have also shown elevated risk associated with exposure to full-mouth dental X-rays, although it is thought that this 


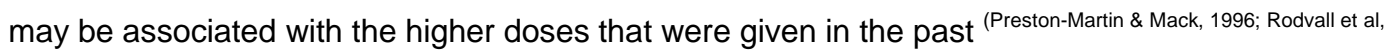
1998).

Other environmental exposures for which associations with meningioma have been observed include extremely low frequency electromagnetic fields (Baldi et al, 2011), herbicides in women but not in men (Samanic et al, 2008), and lead (Hu et al 1999; Navas-Acién et al 2002) (most apparent in individuals with the ALAD G177C polymorphism (Rajaraman et al 2006) $)$. A number of occupations with potential exposure to organic solvents have also been implicated as risk factors for meningioma. The highly lipophilic nature of organic solvents means that they are readily absorbed through the respiratory system and skin, and readily cross the blood-brain barrier, where the resulting irritation of cell membranes and tissues cause neurotoxicity (Bale, et al, 2011). In a Chinese case-control study (Hu et al, 1999) a nonsignificantly elevated risk was observed in individuals with occupational exposure to petrol or diesel oil, or to benzene, while in another Swedish study (Navas-Acién et al 2002) a significantly elevated risk was observed in those estimated to have "possible" exposure to solvents although no risk was apparent in those with "probable" solvent exposure. Significantly elevated risks have also been observed in a US case-control study in potentially solvent exposed occupations including automotive body and related repairers, automotive body painters and designers and decorators, with a suggestion of a dose-response relationship, however the numbers of cases were small and the confidence intervals wide (Rajaraman et al 2004). Other studies, however, have found no association

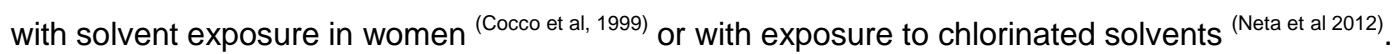

In recognition of the paucity of information on the aetiology of meningioma the Brain Tumour Epidemiology Consortium recently released a consensus document recommending further epidemiological research into risk factors for meningioma, with improved exposure assessment,

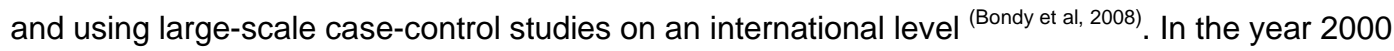
an international group mounted a study of glioma, meningioma, acoustic neurinoma and malignant parotid gland tumours in order to evaluate possible carcinogenic effects of mobile phone use (the 
INTERPHONE study). The study design and epidemiological methods, and a description of the INTERPHONE study population, are described in detail elsewhere (Cardis et al, 2007). An important additional component of the INTERPHONE study was the inclusion by seven of the participating countries (Australia, Canada, France, Germany, Israel, New Zealand and the United Kingdom) of an additional section in the study questionnaire obtaining a complete occupational history of all jobs held for more than 6 months to investigate associations with occupational exposure to selected chemical agents.

The information collected from these seven countries has been further analysed for the Occupational Exposure and Brain Cancer (INTEROCC) study, using improved exposure assessment methods to evaluate the effects of exposure to selected chemicals in the workplace on the risk of brain cancer. For this component of the INTEROCC study in which we evaluate risk factors for meningioma a total of 1,906 cases and 5,565 population based controls were included, making this by far the largest case-control study of meningioma after the INTERPHONE study. In this paper we present results for occupational exposure to a range of organic solvents. 


\section{Methods}

\section{The case-control study}

The INTEROCC study is a multi centre population-based case-control study conducted between 2000 and 2004 in 10 study centres from 7 countries; namely Australia, Canada, France, Germany, Israel, New Zealand and the United Kingdom. In most centres the study population consisted of all residents in the study regions aged 30 to 59 , with eligible cases being all residents of those regions diagnosed during the study period with a confirmed first primary meningioma. The age range of cases varied in some centres, with cases up to the age of 69 years included in Germany, cases aged 18 to 69 in the UK, and in Israel cases aged 18+ years were recruited to allow for greater case ascertainment. Controls were randomly selected from the source population in each centre, either individually matched or frequency matched on year of birth (within 5-year categories), sex and study region. Wherever possible study subjects were interviewed face-to-face by trained interviewers using a computer assisted personal interview (CAPI) questionnaire, although a small number of proxy interviews were conducted where the study subject had died or was too ill to be interviewed. The study questionnaire covered demographic factors, including socio-economic and lifestyle factors, and a full occupational history.

\section{Occupational exposure assessment}

The occupational history information obtained included all jobs held for at least six months, the job title, the specific tasks performed in that job, the company name, a description of the activities performed by the company, and the start and end year of each job. An occupational hygienist from each of the seven participating countries coded local jobs according to the international occupation and industry classifications, i.e. the International Standard Classification of Occupations 1968

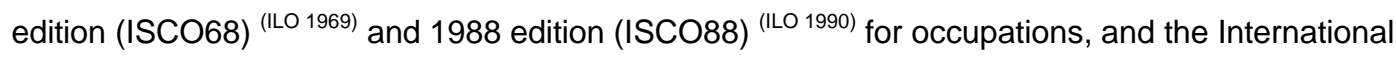
Standard Industrial Classification 1971 edition (ISIC71) (ILO 1975) for industry. To maximise the quality and comparability of coding between countries a common set of coding guidelines was 
established, a group training exercise was held and a web-based forum was established to discuss difficult cases. Before and after comparison trials were conducted to determine the reliability of coding between different countries, which showed that the reliability was moderately improved (McLean et al., 2011).

Based on a review of the literature in relation to possible occupational risk factors for brain cancer, a total of 29 chemical agents, including selected organic solvents, combustion products, metals, dusts, formaldehyde, oil mist and sulphur dioxide were selected for investigation in the INTEROCC study. The retrospective assessment of exposure to the selected chemicals for all study participants was made by linking the occupational history information to a newly developed JobExposure Matrix based on the Finnish job-exposure matrix (FINJEM) ${ }^{(\text {Kauppinen et al, 1998) }}$. The methods used to infer exposure, including the modification of the FINJEM using exposure estimates developed for a population-based case-control study of lung cancer in Montréal (Lavoué et al, 2012) to develop the INTEROCC-JEM, as well as peer review by an international panel of occupational hygienists to ensure that INTEROCC-JEM estimates better reflected the prevailing exposure patterns in the seven participating countries, have been described in detail elsewhere (van Tongeren et al, 2013).

For this component of the INTEROCC study occupational exposure to the following organic solvents was assessed; Aliphatic and Alicyclic hydrocarbons (ALHC), Aromatic hydrocarbons (ARHC), Toluene (TOLU), Benzene (BENZ), Chlorinated hydrocarbon solvents $(\mathrm{CHC})$, Perchloroethylene (PER), Methylene chloride (MCH), 1,1,1-Trichloroethane (TCE), and Trichloroethylene (TRI), Gasoline (GASO), and Other organic solvents (OSOL). The INTEROCCJEM assigns both $P$ (proportion of workers in that occupation who were considered to be exposed) and I (intensity of exposure), and for the main analyses it was decided to assign exposure only to those occupations where the estimated prevalence of exposure in that job category was greater 
than or equal to $25 \%$ ( $P \geq 25 \%)$. A minimum period of exposure of 1 year was applied, and to allow for latency a lag period of 5 years was also applied.

\section{Statistical analysis}

Conditional logistic regression models were used to calculate odds ratios (ORs) and 95\% confidence intervals $(95 \% \mathrm{Cls})$ for risk of meningioma. Models were stratified by sex, age (5 year groups) and country-region, and adjusted for education. Three exposure indices were used, 1) ever/never exposed, 2) lifetime cumulative exposure categorised in quartiles of the distribution among exposed controls, and 3) total duration of exposure in categories decided a priori of 1-4 years, 5-14 years and >15 years. All subjects never exposed to "any solvent" were used as the reference category. Sensitivity analyses were conducted by excluding proxy respondents, subjects over 69 years and subjects with neurofibromatosis and tuberous sclerosis, and by including those with uncertain exposure (i.e. duration of exposure $<1$ year) in the unexposed group. We also repeated the analyses using different cut-off points for defining exposure (i.e. $P \geq 5 \%, P \geq 50 \%$ ), and using different lag periods (i.e. 1, 5 and 10 years). 


\section{Results}

Table 1 describes selected characteristics of the study population of the 1,906 meningioma cases and 5,565 controls that were included in the analyses. The majority of cases $(73.4 \%)$ were women, the mean age at diagnosis was 55 years, and the majority of cases $(60.1 \%)$ had at most a primary or secondary education. A total of $4.6 \%$ of the case interviews were conducted with a proxy respondent. Overall participation rates were $81 \%$ for cases and $50 \%$ for controls.

The lifetime occupational exposure prevalence, mean cumulative exposure and mean duration of exposure to organic solvents is shown in Table 2 . Where $\mathrm{P} \geq 25 \%$ a total of $6.5 \%$ of all participants were ever exposed to any solvent, with a greater proportion of controls $(7 \%)$ ever exposed to any solvent compared to cases (5\%). Where $P \geq 5 \%$ was used as a cut point a total of $14.3 \%$ of participants were ever exposed to any solvent, while where a cut point of $P \geq 50 \%$ was used the total ever exposed was $4.7 \%$. The specific solvents with the greatest number of participants ever exposed at $\mathrm{P} \geq 25 \%$ were aromatic hydrocarbons (ARHC) $5.7 \%$, aliphatic and alicyclic hydrocarbons (ALHC) 2.5\%, toluene (TOLU) 2.3\% and other organic solvents (OSOL) 1.6\%. Of the chlorinated hydrocarbons no cases were ever exposed to Methylene chloride $(\mathrm{MCH})$, Perchloroethylene (PER) or Trichloroethylene (TRI), and only one case was exposed to 1,1,1Trichloroethane (TCE). The highest mean cumulative exposures were for ARHC (10,464.20 ppm) and TOLU $(10,446.80 \mathrm{ppm})$, while the longest mean durations of exposure were to OSOL (12.4 years), ARHC (10.9 years), ALHC (10.4 years) and TOLU (10.3 years). Controls tended to have greater mean cumulative exposure to all solvents compared to cases, and also tended to have higher mean durations of exposure to all solvents compared to cases with the exception of benzene (BENZ). As can be seen in Table 3, with the exception of those ever exposed to ARHC (where less than $40 \%$ were ever exposed to any other agent) joint exposure to different solvents or classes of solvents was common. 
As can be seen in Table 4 no association was observed between exposure to any solvent and meningioma in the overall study population $(\mathrm{OR}=1.05,95 \% \mathrm{Cl} 0.82-1.36)$, or in women $(\mathrm{OR}=1.02,95 \% \mathrm{Cl} 0.75-1.39)$ or men $(\mathrm{OR}=1.16,95 \% \mathrm{Cl} 0.73-1.84)$ separately. For those specific solvents with at least 5 exposed cases the ORs ranged from 0.65 to 1.33 overall, and none were statistically significant. In internal analyses there were also no significant trends of increasing risk with either increasing cumulative exposure or duration of exposure, either overall or when stratified by gender. Sensitivity analyses excluding proxy respondents, including those with uncertain exposure (less than 1 year in duration) in the reference group, excluding unresponsive respondents, excluding subjects greater than 69 years of age, or excluding subjects with neurofibromatosis or tuberous sclerosis, generally revealed little change in odds ratios (results not shown). Other sensitivity analyses using different cut points to define exposure, and using different lag times, also resulted in little change to odds ratio estimates and showed no significant trends according to exposure duration or cumulative exposure. Similarly analyses including additional potentially confounding variables (socio-economic status, marital status, smoking, use of a proxy, a medical history of atopic conditions, or age at first exposure) in the model also generally resulted in little change in the odds ratios. There was also no significant interaction according to sex, age, age at first exposure, or smoking status for ever exposure (data not shown). 


\section{Discussion}

This multi-centre case-control study of 1,906 cases and 5,565 controls provides no evidence of any association between occupational exposure to organic solvents and meningioma, in the overall study population or in women or men separately. There were also no significant trends of increasing risk with either increasing cumulative exposure or duration of exposure. However, interpretation of these negative findings should take into account the strengths and limitations of the study.

The INTEROCC study is the largest case-control study conducted to date investigating associations between occupational exposure to organic solvents and meningioma. Potential sources of selection and recall bias in the design and conduct of the INTERPHONE study on which this study was based have been addressed in detail elsewhere (Cardis et al, 2007; Vriheid et al, 2009), however these related primarily to the somewhat more problematic issue of recall of cell phone use by study participants and it is unlikely that the same biases would apply to occupational chemical exposure with the methods used in this study to assign exposure. The vast majority of interviews in this study were conducted face-to-face, with only $4.6 \%$ of the case interviews being conducted with a proxy respondent. There were differential response rates between cases and controls (estimated as $81 \%$ of cases and $50 \%$ of controls), however there is little evidence of systematic response bias apart from gender distribution, and to a lesser extent country-region, between cases and controls and these differences were controlled for in the statistical analyses.

The retrospective assessment of occupational exposure is the major challenge in all communitybased case-control studies, particularly in multi centre studies where there may be either true differences in exposure prevalence and intensity between countries or differences in the quality of the exposure estimation made locally (Offermans et al, 2013; Peters et $a l, 2011$ ). The different methods available 
for estimating occupational exposures retrospectively, i.e. analysis by job or industry title, self-

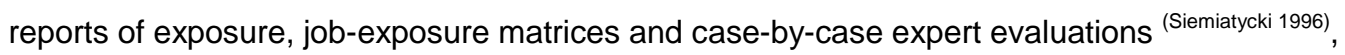
each have advantages and disadvantages and involve some trade-off between cost and validity (Van Tongeren et al, 2013). With over 35,000 jobs having been held by INTEROCC study participants, and the relatively limited information available in the occupational history, the only feasible option for this study was the use of a job-exposure matrix.

Notwithstanding the limitations associated with the use of a job-exposure matrix approach to estimate past exposure, we believe that the process we followed to modify the FINJEM for application to the INTEROCC study resulted in significantly improved consistency and better estimates of exposure across the seven participating countries. The assessment of exposure based on study participants' reported occupational histories and a job-exposure matrix minimises the probability of recall and reporting bias, however assigning a single exposure measure to all subjects when it is known that there is typically wide variability in exposure levels between workers in a given job title does introduce error. This error, however, is non-differential with respect to case/control status and is, therefore, likely to lead to the attenuation of true risk estimates.

A number of previous studies have suggested associations between occupational exposure to organic solvents and meningioma. However, this evidence has come from two relatively small studies using exposure assessment based on responses to specific questions about chemical exposures (Hu et al 1999), or analyses using expert assessments to group jobs determined to have similar tasks and exposures (Rajaraman et al, 2004). Another large Swedish study (Navas-Acién et al, 2002) involved linkage of cancer registry data with census data from 1960 and 1970 to determine occupation, and used a Swedish job-exposure matrix to estimate exposure. This study, however, found some evidence of an association with "possible" exposure but not with "probable" exposure to solvents. Despite the large sample size in the INTEROCC study the prevalence of exposure to chlorinated hydrocarbons was extremely low with only one case ever exposed to a chlorinated 
hydrocarbon. We were unable, therefore, to assess risk associated with exposure to Methylene chloride, perchloroethylene, 1,1,1-Trichloroethane or trichloroethylene, however the exposure prevalence was adequate for the other solvents. The recent US study (Neta et al, 2012) using expert assessment to estimate exposure found no evidence of an association between occupational exposure to chlorinated hydrocarbon solvents and meningioma.

In conclusion, this study provides no evidence of an association between occupational exposure to selected organic solvents and meningioma. 


\section{Acknowledgements}

We would like to thank Timo Kauppinen of the Finnish Institute of Occupational Health for allowing us to use and modify the FINJEM as well as sharing his valuable expertise on the exposure assessment committee in the company of Nils Plato of the Karolinska Institute in Stockholm. Jordi Figuerola and Rodrigo Villegas of CREAL have been the backbone of the team in cleaning and preparing the data for analysis. The authors would like to thank Avital Jarus-Hakak (Israel), Louise Nadon (Canada), Florence Samkange-Zeeb (Germany), Anne Sleeuwenhoek (UK), and Hélène Tardy (France) who coded occupations and assisted in the data clean-up. We are grateful to Drs Bruce Armstrong (Australia), Mary McBride (Canada), Maria Blettner (Germany), Joachim Schüz (Germany), Alistair Woodward (New Zealand) and Patricia McKinney (U.K.) for the use of the occupational data from their INTERPHONE study centres for the INTEROCC project.

\section{Funding}

This work was funded by the National Institutes for Health (NIH) Grant No. 1R01CA124759-01. Coding of the French occupational data was in part funded by AFSSET (Convention No ST-2005004). The INTERPHONE study was supported by funding from the European Fifth Framework Program, 'Quality of Life and Management of Living Resources' (contract 100 QLK4-CT1999901563) and the International Union against Cancer (UICC). The UICC received funds for this purpose from the Mobile Manufacturers' Forum and GSM Association. In Australia, funding was received from the Australian National Health and Medical Research 5 Council (EME Grant 219129) with funds originally derived from mobile phone service licence fees; a University of Sydney Medical Foundation Program; the Cancer Council NSW and The Cancer Council Victoria. In Canada funding was received from the Canadian Institutes of Health Research (project MOP42525); the Canada Research Chair programme; the Guzzo-CRS Chair in Environment and Cancer; the Fonds de la recherche en sante du Quebec; the Canadian Institutes of Health Research (CIHR), the latter including partial support from the Canadian Wireless Telecommunications Association; the NSERC/SSHRC/McLaughlin Chair in Population Health Risk Assessment at the University of Ottawa. In France, funding was received by l'Association pour la Recherche sur le Cancer (ARC) (Contrat N85142), the French Agency for Food, Environmental and Occupational Health and Safety (ANSES; Contract No ST-2005-004) and three network operators (Orange, SFR, Bouygues Telecom). In Germany, funding was received from the German Mobile Phone Research Program (Deutsches Mobilfunkforschungsprogramm) of the German Federal Ministry for the Environment, Nuclear 45 Safety, and Nature Protection; the Ministry for the Environment and Traffic of the state of Baden- Wurttemberg; the Ministry for the Environment of the state of North Rhine-Westphalia; the MAIFOR Program (Mainzer 
Forschungsforderungsprogramm) of the University of Mainz. In New Zealand, funding was provided by the Health Research Council, Hawkes Bay Medical Research Foundation, the Wellington Medical Research Foundation, the Waikato Medical Research Foundation and the Cancer Society of New Zealand. Additional funding for the UK study was received from the Mobile Telecommunications, Health and Research (MTHR) program, funding from the Health and Safety Executive, the Department of Health, the UK Network Operators (O2, Orange, T-Mobile, Vodafone, '3') and the Scottish Executive. 


\section{References}

Anttila A, Heikkila P, Nykyri E, et al. Risk of nervous system cancer among workers exposed to lead. J. Occup. Environ. Med. 1996;38(2):131-136.

Baldi I, Coureau G, Jaffré A, Gruber A, Ducamp S, Provost D, Lebailly P, Vital A, Loiseau H, Salamon R. Occupational and residential exposure to electromagnetic fields and risk of brain tumors in adults: a case-control study in Gironde, France. Int J Cancer 2011; 129 : 1477-1484.

Bale AS, Barone S Jr, Scott CS, Cooper GS. A review of potential neurotoxic mechanisms among three chlorinated organic solvents. Toxicol Appl Pharmacol 2011; 255: 113-126.

Bhatti P, Stewart PA, Hutchinson A, et al. Lead exposure, polymorphisms in genes related to oxidative stress, and risk of adult brain tumors. Cancer Epidemiol. Biomarkers Prev. 2009;18(6):1841-1848.

Bondy ML, Scheurer ME, Malmer B, et al. Brain tumor epidemiology: Consensus from the Brain Tumor Epidemiology Consortium. Cancer 2008;113(7 Special Issue SI):1953-1968.

Cardis E, Richardson L, Deltour I, et al. The INTERPHONE study: design, epidemiological methods, and description of the study population. Eur. J. Epidemiol. 2007;22(9):647-664.

Claus EB, Bondy ML, Schildkraut JM, Wiemels JL, Wrensch M, Black PM. Epidemiology of intracranial meningioma. Neurosurgery 2005; 57: 1088-1095.

Cocco P, Heineman EF, Dosemeci M. Occupational risk factors for cancer of the central nervous system (CNS) among US women. Am. J. Ind. Med. 1999;36(1):70-74.

Connelly JM, Malkin MG. Environmental risk factors for brain tumors. Current Neurology \& Neuroscience Reports 2007;7(3):208-214.

Fisher JL, Schwartzbaum JA, Wrensch M, Wiemels JL. Epidemiology of brain tumors [Review]. Neurol. Clin. 2007;25(4):867-90.

Heineman EF, Cocco P, Gomez MR, et al. Occupational exposure to chlorinated aliphatic hydrocarbons and risk of astrocytic brain cancer. Am. J. Ind. Med. 1994;26(2):155-169.

Helseth A, Mork SJ, Glattre E. Neoplasms of the central nervous system in Norway. V. Meningioma and cancer of other sites. An analysis of the occurrence of multiple primary neoplasms in meningioma patients in Norway from 1955 through 1986. APMIS 1989;97(8):738-744.

Hu J, Little J, Xu T, Zhao X, Guo L, Jia X, Huang G, Bi D, Liu R. Risk factors for meningioma in adults: a case-control study in Northeast China. Int J Cancer 1999; 83: 299-304.

International Labour Office. International Standard Classification of Occupations: ISCO-88. Geneva: International Labour Office; 1990.

International Standard Industrial Classification of all Economic Activities (Revision 2). New York: United States; 1975. 266 p.

Kauppinen T, Toikkanen J, Pukkala E. From cross-tabulations to multipurpose exposure information systems-a new jon-exposure matrix. Am J Ind Med 1998; 33: 409-17.

Lavoué J, Pintos J, Van Tongeren $\mathrm{M}$ et al. Comparison of exposure estimates in the Finnish jobexposure matrix FINJEM with a JEM derived from expert assessments performed in Montreal. Occup Environ Med 2012; 69: 465-71.

McLean D, van Tongeren M, Richardson L, Schlehofer B, Villegas R, Benke G, Jarus-Haka A, Hours M, Nadon L, Samkange-Zeeb F, Sleeuwenhoek A, Cardis E, for the INTEROCC study group. Evaluation of the quality and comparability of job coding across seven countries in the INTEROCC study. EPICOH 2011: $23^{\text {rd }}$ International Conference on Epidemiology in Occupational Health. 7-9 September 2011. Oxford, UK: University of Oxford.

Musicco M, Sant M, Molinari S, Filippini G, Gatta G, Berrino F. A case-control study of brain gliomas and occupational exposure to chemical carcinogens: the risk to farmers. Am. J. 
Epidemiol. 1988;128(4):778-785.

Navas-Acién A, Pollán M, Gustavsson P, Plato N. Occupation, exposure to chemicals and risk of gliomas and meningiomas in Sweden. Am J Ind Med 2002; 42: 214-227.

Neta G, Stewart PA, Rajaraman P, Hein MJ, Waters MA, Purdue MP, Samanic C, Coble JB, Linet MS, Inskip PD. Occupational exposure to chlorinated solvents and risks of glioma and meningioma in adults. Occup Environ Med 2012; 69: 793-801.

Offermans NSM, Vermeulen R, Burdorf A, Peters S, Goldbohm RA, Koeman T, van Tongeren M, Kauppinen T, Kant I, Kromhout H, van den Brandt PA. Comparison of expert and jobexposure matrix-based retrospective exposure assessment of occupational carcinogens in the Netherlands Cohort Study. Occup Environ Med 2012; 69: 745-751.

Peters S, Vermeulen R, Cassidy A, 't Mannetje A, van Tongeren M, Boffetta P, Straif K, Kromhout $\mathrm{H}$, on behalf of the INCO Group. Comparison of exposure assessment methods for occupational carcinogens in a multi-centre lung cancer case-control study. Occup Environ Med 2011; 68: 148-153.

Preston-Martin S, Mack W, Henderson BE. Risk factors for gliomas and meningiomas in males in Los Angeles County. Cancer Res. 1989;49(21):6137-6143.

Rajaraman P, De Roos AJ, Stewart PA, Linet MS, Fine HA, Shapiro WR, Selker RG, Black PM, Inskip PD. Occupation and risk of meningioma and acoustic neuroma in the United States. Am J Ind Med 2004; 45: 395-407.

Rodvall Y, Ahlbom A, Spannare B, Nise G. Glioma and occupational exposure in Sweden, a casecontrol study. Occup. Environ. Med. 1996;53(8):526-532.

Rodvall Y, Ahlbom A, Pershagen G, Nylander M, Spännare B. Dental radiography after age 25 years, amalgam fillings and tumours of the central nervous system. Oral Oncol. 1998; 34(4): 265-9.

Ron E, Modan B, Boice JD Jr, Alfandary E, Stovall M, Chetrit A, Katz L. Tumors of the brain and central nervous system after radiotherapy in childhood. N Engl J Med. 1988; 319(16): 1033-9.

Ruder AM, Carreon T, Butler MA, et al. Exposure to farm crops, livestock, and farm tasks and risk of glioma. Am. J. Epidemiol. 2009;169(12):1479-1491.

Sadetzki S, Chetrit A, Freedman L, Stovall M, Modan B, Novikov I. Long-term follow-up for brain tumor development after childhood exposure to ionizing radiation for tinea capitis. Radiat Res. 2005 Apr;163(4):424-32.

Schneider B, Pulhorn H, Rohrig B, Rainov NG. Predisposing conditions and risk factors for development of symptomatic meningioma in adults. Cancer Detect. Prev. 2005;29(5):440447.

Schoenberg BS, Christine BW, Whisnant JP. Nervous system neoplasms and primary malignancies of other sites. The unique association between meningiomas and breast cancer. Neurology 1975;25(8):705-712.

Siemiatycki J. Exposure assessment in community-based studies of occupational cancer. Occup Hyg 1996; 3: 41-58.

Smith FP, Slavik M, MacDonald JS. Association of breast cancer with meningioma: report of two cases and review of the literature. Cancer 1978;42(4):1992-1994.

Samanic CM, De Roos AJ, Stewart PA, Rajaraman P, Waters MA, Inskip PD. Occupational exposure to pesticides and risk of adult brain tumours. Am J Epidemiol 2008; 167: 976-985.

International Labour Office. International Standard Classification of Occupations, Revised Edition 1968. Geneva: International Labour Organization; 1969.

Van Tongeren M, Kincl L, Richardson L, Benke G, Figuerola J, Kauppinen T, Lakhani R, Lavoué J, McLean D, Plato N, Cardis E for the INTEROCC Study Group. Assessing occupational exposure to chemicals in an international epidemiological study of brain tumours. Ann 
Occup Hyg Manuscript ID: AnnHyg-12-0136.R1

Viel JF, Challier B, Pitard A, Pobel D. Brain cancer mortality among French farmers - the vineyard pesticide hypothesis. Arch. Environ. Health 1998;53(1):65-70.

Vrijheid M, Richardson L, Armstrong BK, Auvinen A, Berg G, Carroll M, Chetrit A, Deltour I,

Feychting M, Giles GG et al. Quantifying the impact of selection bias caused by nonparticipation in a case-control study of mobile phone use. Ann Epidemiol 2009; 19: 33-41.

Wrensch M, Minn Y, Chew T, Bondy M, Berger MS. Epidemiology of primary brain tumors: Current concepts and review of the literature. Neuro-Oncology 2002;4(4):278-299.

Wesseling C, Pukkala E, Neuvonen K, Kauppinen T, Boffetta P, Partanen T. Cancer of the brain and nervous system and occupational exposures in Finnish women. J Occup Environ Med 2002; 44: 663-668.

Wiemels J, Wrensch M, Claus EB. Epidemiology and etiology of meningioma. J Neurooncol 2010; 99: 307-314. 


\begin{tabular}{|c|c|c|c|c|}
\hline & \multicolumn{2}{|c|}{ Cases } & \multicolumn{2}{|c|}{ Controls } \\
\hline & $\mathrm{n}$ & $\%$ & $\mathrm{n}$ & $\%$ \\
\hline Total & 1,906 & & 5,565 & \\
\hline \multicolumn{5}{|l|}{ Sex } \\
\hline Males & 507 & 26.6 & 2,484 & 44.6 \\
\hline Females & 1,399 & 73.4 & 3,081 & 55.4 \\
\hline \multicolumn{5}{|l|}{ Country } \\
\hline Australia & 254 & 13.3 & 669 & 12 \\
\hline Canada & 94 & 4.9 & 653 & 11.7 \\
\hline France & 145 & 7.6 & 472 & 8.5 \\
\hline Germany & 379 & 19.9 & 1,535 & 27.6 \\
\hline Israel & 737 & 38.7 & 987 & 17.7 \\
\hline NZ & 50 & 2.6 & 160 & 2.9 \\
\hline UK & 247 & 13.0 & 1,092 & 19.6 \\
\hline \multicolumn{5}{|l|}{ Age (years) } \\
\hline$<25$ & 4 & 0.2 & 33 & 0.6 \\
\hline $25-34$ & 79 & 4.1 & 390 & 7 \\
\hline $35-44$ & 272 & 14.3 & 1,117 & 20.1 \\
\hline $45-54$ & 658 & 34.5 & 1,765 & 31.7 \\
\hline $55-64$ & 524 & 27.5 & 1,529 & 27.5 \\
\hline $65-74$ & 252 & 13.2 & 582 & 10.5 \\
\hline $75-84$ & 102 & 5.4 & 132 & 2.4 \\
\hline $85+$ & 15 & 0.8 & 17 & 0.3 \\
\hline \multicolumn{5}{|l|}{ Smoking } \\
\hline Current & 486 & 25.5 & 1,501 & 27 \\
\hline Ex & 397 & 20.8 & 1,319 & 23.7 \\
\hline Never & 1,023 & 53.7 & 2,745 & 49.3 \\
\hline \multicolumn{5}{|l|}{ Maximum level of education attained } \\
\hline Primary, Secondary & 1,146 & 60.1 & 2,998 & 53.9 \\
\hline Intermediate college, professional & 361 & 18.9 & 1,045 & 18.8 \\
\hline Tertiary & 392 & 20.6 & 1,511 & 27.2 \\
\hline Unknown & 7 & 0.4 & 11 & 0.2 \\
\hline \multicolumn{5}{|l|}{ SIOPS* SES scale in quartiles } \\
\hline$<35$ & 550 & 28.9 & 1,369 & 24.6 \\
\hline $35-42.8$ & 439 & 23 & 1,369 & 24.6 \\
\hline $42.9-52$ & 417 & 21.9 & 1,369 & 24.6 \\
\hline $52.1+$ & 421 & 22.1 & 1,369 & 24.6 \\
\hline Unknown & 79 & 4.1 & 90 & 1.6 \\
\hline \multicolumn{5}{|l|}{ Marital status } \\
\hline Single, divorced and widowed & 465 & 24.4 & 1,306 & 23.4 \\
\hline Married & 1,434 & 75.2 & 4,244 & 76.3 \\
\hline Don't know/Missing data & 7 & 0.4 & 15 & 0.3 \\
\hline \multicolumn{5}{|l|}{ Benign or Malignant } \\
\hline NA & - & - & 5,565 & 100 \\
\hline Malignant & 15 & 0.8 & - & - \\
\hline Benign & 1,891 & 99.2 & - & - \\
\hline
\end{tabular}

*Standard International Occupational Prestige Scale 


\begin{tabular}{|c|c|c|c|c|c|c|c|c|}
\hline \multirow[b]{2}{*}{ Agent } & \multicolumn{4}{|c|}{ Cases } & \multicolumn{4}{|c|}{ Controls } \\
\hline & $\begin{array}{c}\text { Ever } \\
\text { (n) }\end{array}$ & $\begin{array}{l}\text { Ever } \\
(\%)\end{array}$ & $\begin{array}{l}\text { Mean } \\
\text { cumulative } \\
\text { exposure } \\
\text { (ppm) }\end{array}$ & $\begin{array}{c}\text { Mean } \\
\text { duration of } \\
\text { exposure } \\
\text { (years) }\end{array}$ & $\begin{array}{c}\text { Ever } \\
(\mathrm{n})\end{array}$ & $\begin{array}{c}\text { Ever } \\
\text { (\%) }\end{array}$ & $\begin{array}{c}\text { Mean } \\
\text { cumulative } \\
\text { exposure } \\
\text { (ppm) }\end{array}$ & $\begin{array}{c}\text { Mean } \\
\text { duration of } \\
\text { exposure } \\
\text { (years) }\end{array}$ \\
\hline Any solvent & 95 & 5 & - & - & 389 & 7 & - & - \\
\hline ALHC & 41 & 2.2 & 6,287 & 8.8 & 139 & 2.6 & 7,261 & 10.9 \\
\hline ARHC & 74 & 3.9 & 9,876 & 10.1 & 351 & 6.4 & 10,588 & 11 \\
\hline BENZ & 13 & 0.7 & 756 & 7.4 & 66 & 1.3 & 1,054 & 4.7 \\
\hline $\mathrm{CHC}$ & 1 & 0.1 & 869 & 1.5 & 13 & 0.3 & 4,614 & 7.6 \\
\hline GASO & 5 & 0.3 & 143 & 4.1 & 25 & 0.5 & 169 & 4.2 \\
\hline $\mathrm{MCH}$ & 0 & 0 & 0 & 0 & 0 & 0 & 0 & 0 \\
\hline OSOL & 27 & 1.5 & 4,509 & 8.9 & 89 & 1.7 & 7,150 & 13.4 \\
\hline PER & 0 & 0 & 0 & 0 & 0 & 0 & 0 & 0 \\
\hline TCE & 1 & 0.1 & 188 & 1.5 & 3 & 0.1 & 458 & 3.7 \\
\hline TOLU & 36 & 1.9 & 9,399 & 9 & 128 & 2.4 & 10,742 & 10.6 \\
\hline TRI & 0 & 0 & 0 & 0 & 11 & 0.2 & 3,521 & 6.1 \\
\hline
\end{tabular}

* Exposure in an occupation where $\mathrm{P} \geq 25 \%$ in Job-Exposure Matrix for at least 1 year with a 5-year lag. 


\begin{tabular}{lrrrrrrrrrrr}
\hline \multicolumn{10}{c}{ Table 3: Joint exposure to solvents in the INTEROCC study* } \\
\hline \multicolumn{1}{c}{ ALHC } & ARHC & BENZ & CHC & GASO & MCH & OSOL & PER & TCE & TOLU & TRI \\
$n$ & 180 & 425 & 79 & 14 & 30 & 0 & 116 & 0 & 4 & 164 & 11 \\
ALHC & \multicolumn{1}{r|}{} & 33.6 & 46.8 & 35.7 & 100.0 & 0.0 & 96.6 & 0.0 & 0.0 & 82.9 & 45.5 \\
ARHC & 79.4 & \multicolumn{1}{c}{-} & 97.5 & 92.9 & 100.0 & 0.0 & 99.1 & 0.0 & 75.0 & 100.0 & 100.0 \\
BENZ & 20.6 & 18.1 & - & 78.6 & 100.0 & 0.0 & 8.6 & 0.0 & 25.0 & 29.9 & 100.0 \\
CHC & 2.8 & 3.1 & 13.9 & - & 0.0 & 0.0 & 4.3 & 0.0 & 100.0 & 3.0 & 100.0 \\
GASO & 16.7 & 7.1 & 38.0 & 0.0 & - & 0.0 & 0.0 & 0.0 & 0.0 & 18.3 & 0.0 \\
MCH & 0.0 & 0.0 & 0.0 & 0.0 & 0.0 & - & 0.0 & 0.0 & 0.0 & 0.0 & 0.0 \\
OSOL & 62.2 & 27.1 & 12.7 & 35.7 & 0.0 & 0.0 & - & 0.0 & 0.0 & 64.6 & 45.5 \\
PER & 0.0 & 0.0 & 0.0 & 0.0 & 0.0 & 0.0 & 0.0 & - & 0.0 & 0.0 & 0.0 \\
TCE & 0.0 & 0.7 & 1.3 & 28.6 & 0.0 & 0.0 & 0.0 & 0.0 & - & 0.0 & 9.1 \\
TOLU & 75.6 & 38.6 & 62.0 & 35.7 & 100.0 & 0.0 & 91.4 & 0.0 & 0.0 & - & 45.5 \\
TRI & 2.8 & 2.6 & 13.9 & 78.6 & 0.0 & 0.0 & 4.3 & 0.0 & 25.0 & 3.0 & - \\
\hline
\end{tabular}

*Values of cells in each column represent the proportion of participants with exposure to solvent A co-exposed to solvent B 


\begin{tabular}{|c|c|c|c|c|c|c|c|c|c|c|c|c|}
\hline \multirow[b]{2}{*}{ Agent } & \multicolumn{4}{|c|}{ ALL } & \multicolumn{4}{|c|}{ MEN } & \multicolumn{4}{|c|}{ WOMEN } \\
\hline & Cases & Controls & $\mathrm{OR}^{*}$ & $95 \% \mathrm{Cl}$ & Cases & Controls & $\mathrm{OR}^{*}$ & $95 \% \mathrm{Cl}$ & Cases & Controls & $\mathrm{OR}^{*}$ & $95 \% \mathrm{Cl}$ \\
\hline $\begin{array}{l}\text { Never } \\
\text { exposed }\end{array}$ & 1,811 & 4,849 & 1.00 & Reference & 441 & 1,922 & 1.00 & Reference & 1,370 & 2,927 & 1.00 & Reference \\
\hline $\begin{array}{l}\text { Ever } \\
\text { exposed }\end{array}$ & 95 & 349 & 1.05 & $0.82-1.36$ & 66 & 287 & 1.02 & $0.75-1.39$ & 29 & 62 & 1.16 & $0.73-1.84$ \\
\hline ALHC & 41 & 122 & 1.22 & $0.84-1.79$ & 25 & 87 & 1.31 & $0.81-2.12$ & 16 & 35 & 1.11 & $0.60-2.06$ \\
\hline ARHC & 74 & 314 & 0.94 & $0.71-1.25$ & 54 & 270 & 0.89 & $0.64-1.24$ & 20 & 44 & 1.14 & $0.66-1.98$ \\
\hline BENZ & 13 & 60 & 0.65 & $0.35-1.21$ & 7 & 36 & 0.70 & $0.30-1.64$ & 6 & 24 & 0.60 & $0.24-1.50$ \\
\hline $\mathrm{CHC}$ & 1 & 12 & 0.28 & $0.04-2.19$ & 1 & 7 & 0.68 & $0.08-5.93$ & 0 & 5 & - & - \\
\hline GASO & 5 & 21 & 0.73 & $0.27-2.01$ & 1 & 9 & 0.58 & $0.07-4.97$ & 4 & 12 & 0.79 & $0.25-2.51$ \\
\hline OSOL & 27 & 79 & 1.33 & $0.84-2.12$ & 19 & 67 & 1.21 & $0.70-2.08$ & 8 & 12 & 1.84 & $0.73-4.63$ \\
\hline TCE & 1 & 2 & 1.40 & $0.11-18.44$ & 0 & 1 & 0.00 & - & 1 & 1 & 4.80 & $0.20-113.04$ \\
\hline TOLU & 36 & 114 & 1.16 & $0.78-1.73$ & 23 & 89 & 1.09 & $0.66-1.78$ & 13 & 25 & 1.35 & $0.68-2.69$ \\
\hline
\end{tabular}

*ORs for Ever/Never exposed ( $\mathrm{P}>25 \%$ in JEM) with at least one year of exposure and a 5-year lag. 